\title{
Impact of the Current Conflict on Small and Medium-sized Enterprises in Yemen
}

\author{
Mohammed Mostafa Mohammed Qaied ${ }^{1}$ | Kundan Basavaraj ${ }^{2}$ \\ ${ }^{1}$ Department of Postgraduate studies and Research in Commerce Kuvempu University, JnanaSahyadri, Shankaraghatta, \\ 577451, India. \\ ${ }^{2}$ Associate professor Department of Commerce, Sahyadri Commerce and Management College Shivamogga, India.
}

\section{To Cite this Article}

Mohammed Mostafa Mohammed Qaied and Kundan Basavaraj, "Impact of the Current Conflict on Small and Medium-sized Enterprises in Yemen", International Journal for Modern Trends in Science and Technology, 6(8): 213-220, 2020.

\section{Article Info}

Received on 17-July-2020, Revised on 02-August-2020, Accepted on 07-August-2020, Published on 16-August-2020.

\section{ABSTRACT}

The most important elements in achieving economic development in all the countries of the world are small and medium enterprises, as they account for the highest percentage of all kinds of economic enterprises of different sizes. The SME sector remains the most main sectors of the Yemeni economy, as the major sources of jobs, growth, and economic diversification. This study aims to identify the impact of the current conflict on Small and medium enterprises in Yemen's economic growth. The study depends entirely on secondary data gathered from various sources to gain a full insight into the extent of the damage suffered by the medium and small enterprises due to the current conflict, which was represented in figures as well as tables included. The results showed several challenges are facing SMEs due to the current conflict which destroyed around 65 percent of the SME's in the country. Moreover, the researcher recommended certain Strategies to boost and improve the role of Small and medium enterprises in the country's economic growth and development and avoiding the challenges.

KEYWORDS:Medium Enterprises, Small Enterprises, Difficulties, Poor, Yemen.

\section{INTRODUCTION}

Yemen is one of the poorest countries in the Middle East and suffers from high levels of poverty, unemployment, and illiteracy through a geographically overlapping infrastructure. That Occupies 151in the world in GDP per capita (UN). The current conflict has greatly impacted the Yemeni economy, leading to high inflation, macroeconomic instability and uncertainty, weak Yemeni riyal, negative GDP, inability to pay public sector salaries, and limited credit and financial services. Where Yemen faces several economic issues the World Bank report on economic prospects in Yemen predicted that poverty will remain high at about $75 \%$ in 2018 and $73 \%$ in 2019 , pointing to the high poverty rate and the deteriorating economic and social conditions (World Bank). According to the report, violent conflicts in Yemen led to a serious deterioration of the country's economic and social conditions. In the Doing Business report according to World Bank, Yemen fell by 5 ranks from 165 in 2015 to 170 (out of 189 economies) in 2016 (as one of the worst 20 countries worldwide). This led to a sharp decline in production and household income levels. It is considered one of the poorest and low developing countries due to its political instability, poor economic performance, the armed clashes 
taking place in different parts of the country, and finally the high rate of poverty and unemployment among people (A. S. Alshebami \& Rengarajan, 2017). Poverty rates rose sharply, with nearly $80 \%$ of the population living on less than $\$ 3.2$ per person per day following the purchasing power parity (World Bank).

In any economy, manufacturing is carried out by medium and small companies without which growth and development become difficult for the economy. The SME sector is an important part of economic development in a country even though it employs many people in various jobs. SMEs are confined to a small number of industries such as supermarkets, call centers, restaurants, crafts, industrial enterprises, and others, in particular, trade and services. Businessmen in this market, although they have enough capital, are not ready to take up new sectors. Small and micro industries were established as a significant place in the Yemen economy. SMEs provide immediate and broad-based action providing a way to ensure a more fair distribution of national income and to smooth an efficient mobilization of capital and skill resources that may remain unused. Nevertheless, small and micro-sized enterprises play a major role in economic development and growth. Besides, Small businesses are a traditional source of domestic economic growth. They can be financed by different sources and on top of them is the Microfinance institutions which finance enterprises and small projects that play a vital role in the betterment of the livelihood of the poor group suffering in the poor communities due to their poverty situation and negligence of the governments to include them in the financial systems (A. S. Alshebami, 2017). Therefore this study focused on the impact of the current conflict on SMEs in Yemen.

\section{PREVIOUS STUDIES}

Manaye (2018). Focused on Small enterprises have become an important contributor to Ethiopia's economy. The purpose of this paper was to highlight one of the basic requirements, namely, access to funding aspects, for small enterprises that are the basis for accelerating economic growth. The target of the paper is to determine the difficulties that have been faced by small businesses in the city of Lita and Sado in obtaining funding from financial institutions by identifying the dominant means of financing small businesses and factors affecting access to finance. From the results of the study, we can conclude that the primary sources of capital impact to reach a credit facility to a large extent, followed by the purchase of fixed assets financed by the main obstacles to access of SMEs to credit facilities. This study recommended that a credit foundation provides programs to educate small and micro enterprises on how to obtain credit facilities. The Navarathne, K. A. S. In 2017 Seek to archive the difficulties faced by a team of successful micro and small business people in Sri Lanka who have obtained small funding to set up or develop their small businesses and study these in the terms of their long-term potential for success. In order to gain a comprehensive understanding of a particular context, the case study approach was introduced as a research methodology. The problems described in the particular context were ever to achieve higher product and service performance, update technologies, work regulations, issues of competitiveness, and infrastructure problems. Tiny and successful micro-entrepreneurs believe that they are successful - but they still want to expand in their enterprises. Abdullah, A., Thomas, B., \& Metcalfe, S.In 2015 Estimating e-business activities in Yemeni small and medium-sized enterprises, as well as investigating the benefits and hurdles to the use of e-commerce in small and medium-sized enterprises in developing countries such as Yemen. And also, about $51 \%$ of small and medium-sized enterprises have been founded for 10 years and below, $49 \%$ over 10 years. The findings show that Yemeni small and medium-sized enterprises are in the early stages of e-business. It also refers to factors that prevent Yemeni small and medium-sized enterprises from embracing e-business. Gichuki, Njeru, \&Tirimba. In 2014 Seek to identify the obstacles Micro and Small Enterprises face in obtaining KangemiHarambee Market credit facilities in Nairobi City County, Kenya. The research showed that the primary obstacles that prevent micro and small businesses from acquiring credit facilities such as high repayment rates, stringent collateral criteria, people's inability to serve as guarantors, the application fees for high credit facilities, and the limited repayment period. Thus, financial institutions are advised to set more flexible, affordable, and attractive funding standards for micro and small businesses.

Alhammadi and Shahadan (2014). Focused on examines the key drivers of small business growth in Yemen. It examined how administrative capacity (financial operations, corporate marketing, and 
company management), business environment determinants (macroeconomic determinants and capital deficiency), and company resources Business, personality traits, and owner characteristics) affect the growth of SME performance. The results showed that the determinants of managerial capabilities and determinants of the business environment affected the performance of the growth of small service institutions in the country. However, the determinants of fixed resources did not show statistically significant effects on these institutions in Yemen. Kais Aliriani.2013.The SME sector plays an important role in the economy of Yemen. SME is the country's leading employer, providing opportunities to thousands of people every year joining the labor market.

(A. S. Alshebami \& Khandare, 2014, 2015c, 2015a, 2015b), in their studies reported that the small and micro enterprises sector in Yemen faces many challenges related to its regulation, support, and infrastructures. The microfinance industry which is considered part of those financing bodies for the sector reported the existence of many obstacles that hinder its growth and development in Yemen. These challenges include but not limited to the high-interest rate, improper management, shortage in the qualified staff, unavailability of professional skills, financial literacy, religious perception, demanded collaterals.

Small and micro-enterprises, however, face immense obstacles, including lack of qualified personnel, raw material obtaining difficulties, lack of technical support, discovering and adopting new technology, etc. Also, unnecessary licensing requirements, as well as taxes and much more, through inefficient and non-transparent government agencies. besides, poor individuals or the so-called entrepreneurs should have an added value and for that, they should have uniqueness such as an entrepreneurial mindset that qualifies them to propose a change and be part of the entrepreneurial world (A. Alshebami, Al-jubari, Alyoussef, \& Raza, 2020).

\section{METHODOLOGY}

In this research, the focus was only on SMEs in one local government, which chosen the Sanaa city as a case study for this research (Capital of Yemen). Therefore this paper seeks to investigate the impact of Small and Medium Enterprises during the current conflict in Yemen. The purpose of this study is to know the size of the damage that affecting by Medium and small enterprises due to conflict and come up recommended certain Strategies to boost and improve the small and medium enterprises' performance in the country. This study is a review paper and it adopts the descriptive method and a survey that aims to explain the business activities and processes among medium and small enterprises in the economy of Yemen during the current economic unrest. Depending on the survey of the available literature. The study depends entirely on secondary data gathered from microfinance organizations, such as Social Fund for Development, Yemen Microfinance Network, International Labour Organization reports, and associated sources, to access the needed data to conduct the review, in reports released by government agencies and world bank, extra primary data was collected for the purposes to gain a full insight about the extent of the damage suffered by the medium and small enterprises due to the current conflict, which was represented figures as well as tables included.

\section{Medium and Small Enterprises in Yemen}

The medium and small industries have been described globally as a growth driver to the economy. This industry is categorized by lower investment requirements, prudent site navigation, and product replacement operational versatility. Small and micro-enterprises are the foundation of economic growth and prosperity in several third world countries. In 1997, The Govt of Yemen has set up the Social Development Fund (SFD), a public institution financed by several foreign donors as well as the Govt of Yemen. Consequently, the Fund's main goal is to help mitigate poverty and reducing unemployment in Yemen by introducing targeted development enterprises. The SFD continues to pursue its objectives as follows through four main programs:

- Program for local development and community.

- Program for the development of small and micro-enterprises.

- Program for an ability Building program

- Program labor-intense work.

The Program for SMED is implemented by the SMED unit that mainly aims at building local ability for providing to micro and small entrepreneurs indirect financial and non-financial services to enhance their participation in the national economy. The application of $\mathrm{MF}$ is implemented through the support of present financial institutions like financial institutions, banks, and companies or by setting up new 
institutions of this sort. The Social Fund for Development has supported several MFIs as well as the Loan Guarantee Program to provide their branches and buildings with integrated solar systems that provide them Alternative energy source which helped them to continue on their business and This will improve their operational efficiency and reduce their financial cost, which will indirectly improve continued access to financial services for small and micro-business owners. SFD was the main supporter of MFIs during the current crisis in Yemen, which lasted more than six years to enable them to continue to provide financial and non-financial services to the income-generating activities of the owner.

\section{Definition}

Small and Micro Enterprises do not have a commonly accepted definition. Regardless of their level of growth, various countries use different measures, the widely utilized metric is the gross number of workers, gross investment, and the turnover of sales. In the background of Yemen, small, medium and micro-enterprise have classified businesses as follows, according to the national SME policy authorized by the Cabinet in 2005 as per given below table:

Table 1. Small and Medium Enterprises Classification

\begin{tabular}{|l|c|l|}
\hline Category & Employees & Capital investment \\
\hline Small enterprises & $6-15$ & RY. 1 Million To RY. 20 Million \\
\hline Medium enterprises & $15-50$ & RY.20 Million To RY. 1 Billion \\
\hline
\end{tabular}

Source:(ministry of industry and trade, Yemen

\section{DISCUSSION}

\section{Types of Medium and Small Enterprises}

There are four different types of enterprises in Yemen that illustrate the below figure.

Figure 1. Type of projects by size

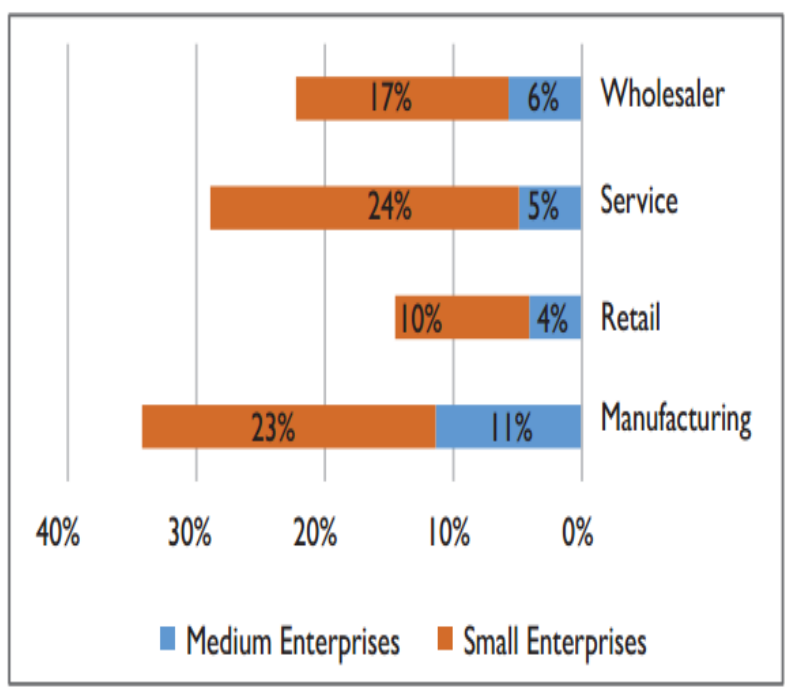

Source: International Labour Urganization report '2018.

According to the survey of the International Labour Organization, it was noted that most of the affected enterprises were small enterprises that represent the majority of business entities in Sana'a with only a few large factories, mainly in Sana'a suburbs. This survey covered different types of projects, 34 percent of the projects were in manufacturing (e.g. factories and workshops), 29 percent were retail (e.g. supermarkets and shops), 22 percent were services (e.g. hotels, hospitals, and restaurants), and 15 percent were wholesalers (as showed figure 1).

\section{The current operational situation}

Most enterprises affected due to the conflict that began in 2015, therefore about 10 percent of the companies remain closed (8 percent were small, 14 percent were medium-sized), while 41 percent opened partially despite extensive damage and operational challenges. (As shown in Figure 2). Of those that were closed, only one organization expected to reopen within 30 days, while the majority (98 percent) did not know when it would reopen again.

Figure 2. Operational status by the size of projects

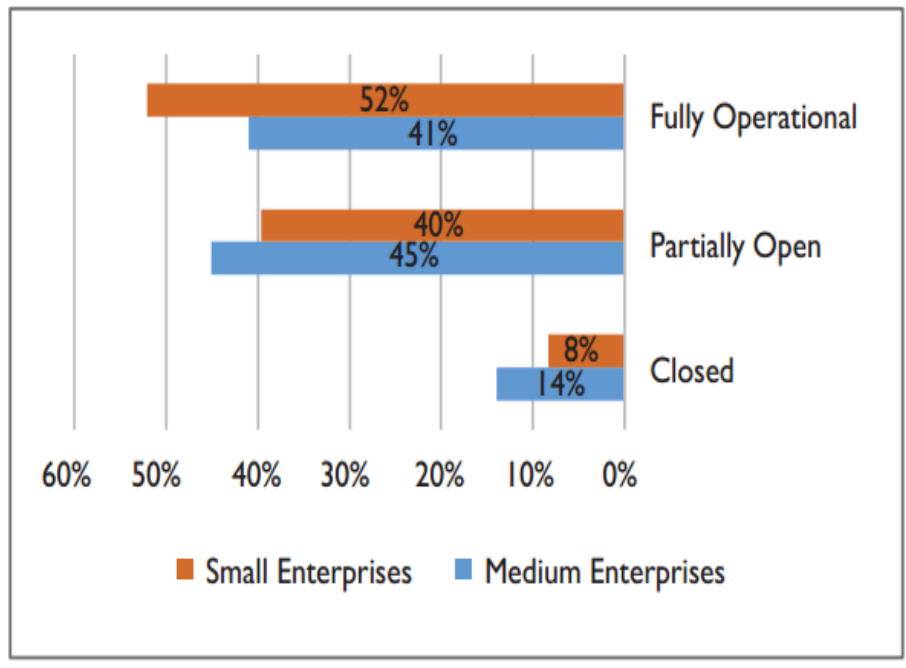

Source: International Labour Organization report 2018 


\section{Level of damage/loss}

The results indicate that 5 percent of SMEs are destroyed (7 percent of medium-sized companies and 4 percent of small projects). At the time of the evaluation, 55 percent of the participating SMEs were still closed, and only 45 percent were partially reopened. While 22 percent of companies received significant damage to human, material, and economic assets, 58 percent were slightly damaged. The damage and losses were mainly caused by airstrikes and their consequences, such as anti-aircraft missiles, looting, and the subsequent economic situation, which showed in figure 3, 4 below.

Figure 3. Size of damage/loss by business size

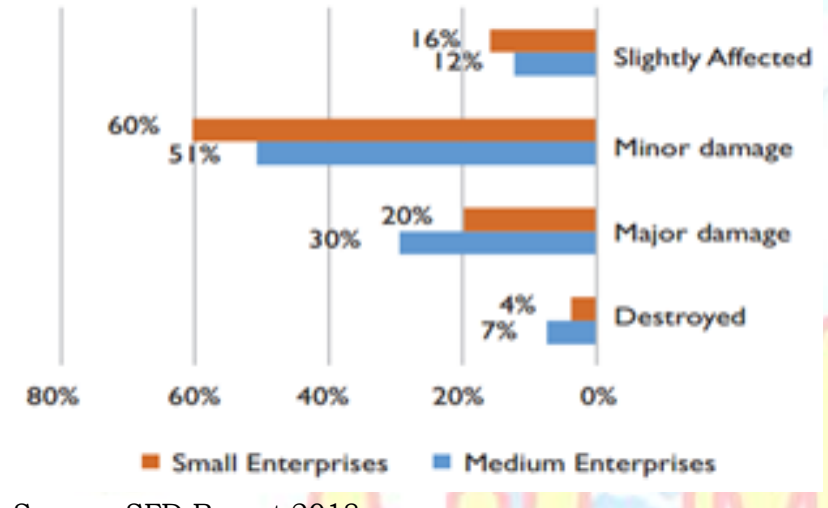

Source: SFD Report 2018

Figure 4. Size of damage/loss

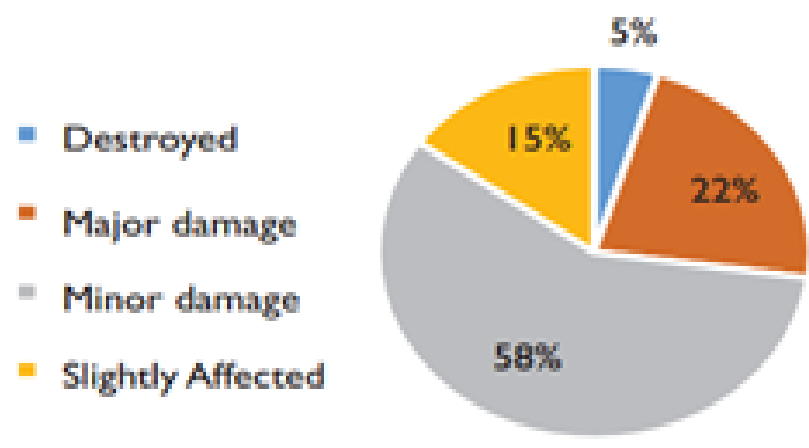

Source: SFD Report 2018

\section{Type of damage/loss}

Since March 2015, SMEs have suffered various types of damage/loss, including material damage to productive assets and infrastructure, loss of life and bodily injury, a significant decrease in their customer base, loss of skilled personnel, limited access to financing, power outages, and other basic services. The World Bank report showed that 40 percent of small and medium-sized enterprises incurred direct human injuries such as employees either killed or injured (51 percent of medium-sized companies and 36 percent of small projects). While
35 percent suffered direct physical damage/loss to buildings, infrastructure, equipment, furniture, raw materials, or final products, etc., 97 percent of all SMEs incurred economic losses such as suspension of trade, and wages paid to workers during Commentary expected revenue losses and customer decline as illustrated in figure 5 below.

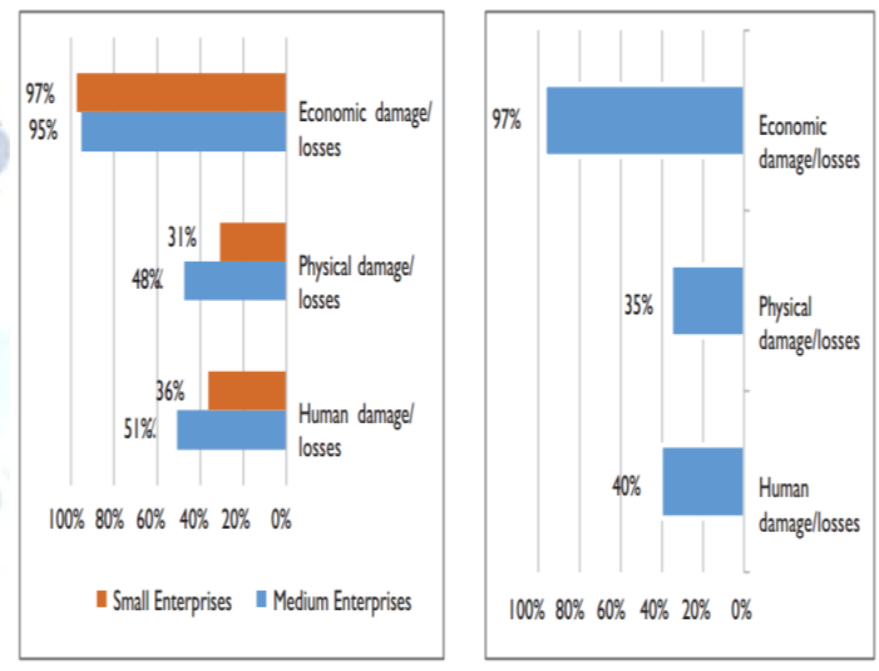

Source: International Labour Organization report 2018.

\section{Human capital damage}

The current conflict not only closed companies but also killed and injured many workers. The evaluation found, 15 workers (all male) were killed, and 84 ( 6 females, 78 males) were injured due to airstrikes and violent shelling. Besides, many workers were fired. The study found a 60 percent decrease in the number of employees in all companies. Table 2 shows the average number of employees before and after the conflict. The numbers include full-time and part-time employees. Part-time workers made up only about 3 percent, so they were added to the number of employees.

Table 2. Human capital damages (average number of workers) by business size

\begin{tabular}{|l|c|c|}
\hline \multicolumn{1}{|c|}{ Category } & Medium Size & Small Size \\
\hline Before conflict & 15.93 & 6.10 \\
\hline (Standard deviation) & $(8.55)$ & $(1.38)$ \\
\hline After conflict & 9.52 & 3.42 \\
\hline (Standard deviation) & $(6.71)$ & $(1.68)$ \\
\hline Total reduction & $60 \%$ & $56 \%$ \\
\hline
\end{tabular}

Source: International Labour Organization report 2018.

\section{Physical damage}

According to the wold bank survey, 41 percent of medium-sized companies and 25 percent of the small firms got damage to buildings. 


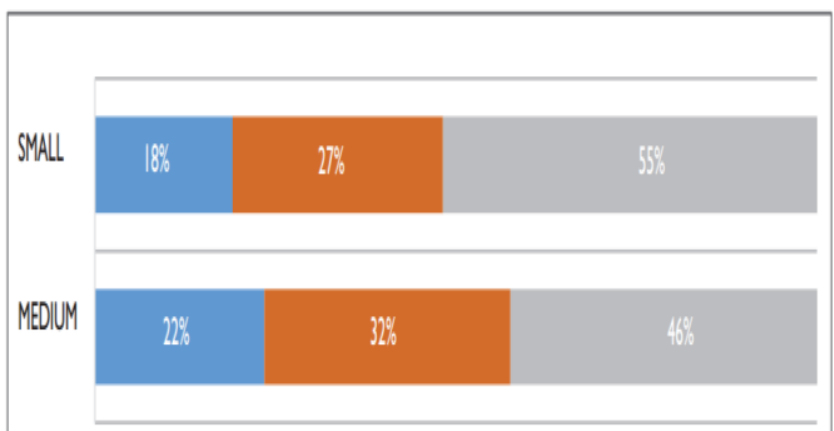

ISevere I Major II Moderate

Figure 6 shows the level of risk among the SMEs that were damaged in the buildings.

Source: World Bank report 2019.

\section{Other physical damage:}

The World Bank survey also included a list of damages that SMEs may have suffered. A third of medium-sized companies lost about two-thirds of their equipment, while the other third lost nearly half of their final merchandise. Table 3 provides a list of all other physical damage identified in the survey and the extent of this damage. For example, 16 percent of medium-sized companies lost about 63 percent of the total raw materials.

Table 3. The extent of other physical damages by the size of business

\begin{tabular}{|c|c|c|c|c|}
\hline \multirow{2}{*}{ Other physical damages } & \multicolumn{2}{|c|}{$\begin{array}{c}\text { Proportion of businesses } \\
\text { with damage }\end{array}$} & \multicolumn{2}{|c|}{ Amount of loss } \\
\cline { 2 - 5 } & Medium-sized & Small & Medium-sized & Small \\
\hline Raw materials & $16 \%$ & $11 \%$ & $63 \%$ & $58 \%$ \\
\hline Finished goods & $24 \%$ & $30 \%$ & $51 \%$ & $43 \%$ \\
\hline Equipment & $34 \%$ & $19 \%$ & $64 \%$ & $48 \%$ \\
\hline Furniture & $28 \%$ & $15 \%$ & $64 \%$ & $52 \%$ \\
\hline Infrastructure & $18 \%$ & $21 \%$ & $68 \%$ & $46 \%$ \\
\hline Vehicles and transport & $23 \%$ & $9 \%$ & $66 \%$ & $57 \%$ \\
\hline Others & $16 \%$ & $1 \%$ & $53 \%$ & $68 \%$ \\
\hline
\end{tabular}

source: worıa Bank report $20 ı y$.

\section{Economic (indirect) damage / loss}

Companies not only suffered material damage, but also faced intangible difficulties that hampered their operations, such as disturbances involving suppliers, customers, investors, and employees, and incurred additional costs to recover. Figure 7 showed a set of barriers along with their degree of influence on SMEs. Product offerings, customer base, and financial loans were affected.
Figure 7. Additional business obstacles facing SMEs by the size of business

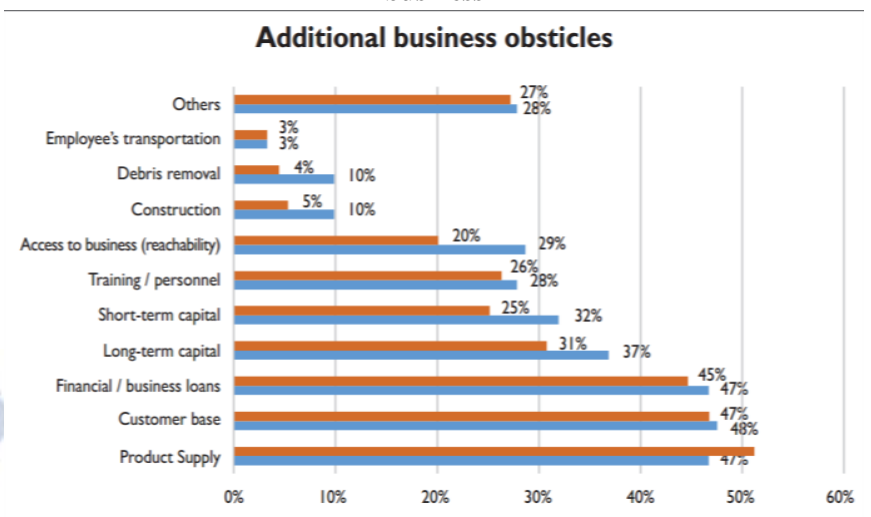

Source: World Bank report 2019.

\section{v. CONCLUSION}

Since March 2015, SMEs have been subjected to various types of damage including material damage to productive assets and infrastructure, loss of lives and personal injuries, a significant decrease in customers, loss of skilled personnel, limited access to finance, power outages, and other of basic services. While the business environment has proven to be a challenge for most companies, whether or not they are affected, those companies that have been directly damaged by airstrikes have incurred greater losses. Most of the devastating effects of airstrikes launched by the coalition forces occurred in 2015. However, as of 2017 , about 10 percent of companies were still closed ( 8 percent of small companies, 14 percent of medium-sized companies), while only 41 percent were partially open. Among closed companies, only one is expected to reopen within 30 days, while 98 percent did not know when it would reopen. According to World Bank survey results show that 5 percent of small and medium-sized companies were destroyed, 22 percent received significant damage to human, material, and economic assets, and 58 percent suffered minor damage.

Moreover, 40 percent of small and medium-sized companies incurred direct human injuries: 15 workers were killed and 84 workers were injured in this sample alone. While 35 percent suffered direct physical damage to buildings, infrastructure, equipment, furniture, raw materials, final products, etc., 97 percent incurred entirely economic losses such as stopping commercial losses, salaries, and workers' wages during the suspension, loss of revenue expectations, and customer decline. Besides, supply chains have been affected and the lack of adequate planning and risk mitigation measures appears to have increased the impact on companies. About 30 
percent of companies have lost at least 50 percent of their fixed assets, and 60 percent of employees have been laid off. Total economic damage to affected firms averaged $\$ 36,844$ among small businesses, and more than $\$ 98,534$ for mid-sized companies, based on just six months of missed opportunities. These numbers were almost twice that of major property damage - about 10 percent of all companies surveyed. Average cash compensation required for a medium-sized organization its turnover is estimated at 15 million riyals $(\$ 40,541)$ and 6.7 million riyals $(\$ 18,108)$ for small businesses.

\section{RECOMMENDATIONS}

To support projects for their early recovery, restoring self-reliance and building resilience among companies in Yemen, the following recommendations should be given first consideration:

1. Recovery initiatives should include the creation and implementation of an integrated program for SME rehabilitation and development restoration, which will include the following:

- Training in business continuity planning and technical and professional reconstruction skills.

- Small grants to replace and upgrade lost productive assets (e.g. equipment and tools).

- Wage subsidies for affected companies to keep their workers.

2. Small and medium-sized enterprises that can return to operational capacity can be identified and selected for assistance according to the following criteria:

- Severely affected.

- Closed or partially open.

- Employing a large number of workers.

- Needing less support to return to business.

- Requiring equipment replacement.

- Holding damaged raw materials.

For more protection of the small and medium enterprises and particularly those projects finance by MFIs, There is a need to change the cultural belief on micro insurance adoption through religious leaders/community spokesperson which prevents people from applying for insurance in general and micro insurance in particular (A. S. Alshebami, Sami A. Morsi, Muhammad Raza, \& Atif Aziz, 2020).

\section{REFERENCES}

[1] Alshebami, A., Al-jubari, I., Alyoussef, I., \&Raza, M. (2020). Entrepreneurial education as a predicator of community college of Abqaiqstudents 'entrepreneur- ial intention.

[2] Alshebami, A., Al-jubari, I., Alyoussef, I., \& Raza, M. (2020). Entrepreneurial education as a predicator of community college of Abqaiq students ' entrepreneur- ial intention. Management Science Letters 10, 10, 3605-3612. https://doi.org/ 10.5267/j.msl.2020.6.033

[3] Alshebami, A. S. (2017). The Role of Microfinance in Mitigating Poverty and Unemplyment in yemen. SRTM University, India-Nanded,Ph.D. thesis.

[4] Alshebami, A. S., \& Khandare, D. M. (2014). Microfinance in Yemen "Challenges and Opportunities ". A Monthly Double-Blind Peer Reviewed Refereed Open Access International e-Journal-Included in the International Serial Directories International Journal in Management and Social Science, 2(12). Retrieved from http://www.ijmr.net.in

[5] Alshebami, A. S., \& Khandare, D. M. (2015a). Islamic Microfinance Industry in Yemen "Challenges and Opportunities." International Journal of Social Work, 2(2). https://doi.org/10.5296/URL

[6] Alshebami, A. S., \& Khandare, D. M. (2015b). The Impact of Interest Rate Ceilings on Microfinance Industry. International Journal of Social Work, 2(2), 10. https://doi.org/10.5296/ijsw.v2i2.7953

[7] Alshebami, A. S., \& Khandare, D. M. (2015c). The Role of Microfinance for Empowerment of Poor Women in Yemen. International Journal of Social Work, 2(1). https://doi.org/ 10.5296/URL

[8] Alshebami, A. S., \& Rengarajan, V. (2017). Microfinance Institutions in Yemen "Hurdles and Remedies." International Journal of Social Work, 4(1), 10. https://doi.org/10.5296/ijsw.v4i1.10695

[9] Alshebami, A. S., Sami A. Morsi, Muhammad Raza, \& Atif Aziz. (2020). Exploring The Potential Of Microinsurance For Challenging The Vulnerabilities In Poverty Sector Of Yemen (An Empirical Study From Demand Side Perspectives ). International Journal of Disaster and Business Continuity, 11(1), 1288-1302.

[10] World Bank 2019. Impact of conflict on private enterprises reports, Yemen.

[11] International Labour Organization 2018. SMALL AND MEDIUM-SIZED ENTERPRISES DAMAGE ASSESSMENT: YEMEN.

[12] Al-Amal Microfinance bank (2018). Available online on http://www.alamalbank.com

[13] Al Kuraimi Bank. (2018). al-kuraimiislamic bank (online) available https://www.kuraimibank.co

[14] Alshebami, \&Khandare, (2015). The Role of Microfinance for Empowerment of Poor Women inUNDP (2009)

[15] Ahmed Al-Maliky, (2012). "Two Million of Youth Involving in Yemeni Economy", www.Alwahda.net.

[16] Ahmed Al-Tayar, (2012 SED in Yemen Facing Finance Difficulties", www.althawra.net.

[17] Adel Mansour. (2011). SMED in Yemen and Future Prospects"SFD Annual Report.

[18] Alhammadi, \&Shahadan, (2014). The determinants of growth performance of small services enterprises in Yemen. JurnalEkonomi Malaysia, 48(1), 35-48.

[19] Abdullah, A., Thomas, B., \& Metcalfe, S. (2015). 1 MEASURING THE E-BUSINESS ACTIVITIES OF SMES IN YEMEN.

[20] European Agency for Safety and Health at Work. (2010). "Risk management basics for SMEs." UK and Finland report. 
[21] Gichuki, J. A. W., Njeru, A., \&Tirimba, O. I. (2014). Challenges facing micro and small enterprises in accessing credit facilities in KangemiHarambee market in Nairobi City County, Kenya. International Journal of Scientific and Research Publications, 4(12), 1-25.

[22] Human Development Report 2009, Overcoming Barriers: Human Mobility and Development. United Nations Development Program. Yemen. International Journal of Scientific and Research Publications, 4(12), 1-25.

[23] Kais Aliriani.2013.Role of SMEs in the Economy: case of Yemen. International Conference, London.

[24] Manaye, M. K. (2018). Challenges for Small and Micro Enterprises in Accessing Finance (Case of WolaitaSoddo Town). Global Journal of Management And Business Research.

[25] Mansour, A. (2011). Small and micro enterprises development in Yemen and Future Prospects. Social Fund for Development-Yemen Brief. http://sfd. sfd-yemen. org/uploads/issues/SMED\% 20Book, 202011-20120716.

[26] Network, Y. (2018). Yemen Microfinance Network. [Online] yemennetwork.org Available at:http://yemennetwork.org/en/.

[27] Navarathne, K. A. S. (2017). Challenges Faced by Small and Micro Enterprises in Sri Lanka. Urban and Regional Planning, 2(6), 34.

[28] Sfd-yemen.org. (2018). Social Fund for Development (SFD) Home page. [Online] Available at: http://www.sfd-yemen.org/.Social Work, 2(1), 36.

[29] Tamer G. I. Mansour. (2018). the Role of Small and Medium Enterprises in Economic Development: Case of Egypt. International Journal of Business Management and Technology.

[30] Undp-yemen.org. (2018). United Nations Development Program (UNDP) - Home page. (Online) Available at:http://www.ye.undp.org/content/yemen/en/home/co untryinfo.html.

[31] World Bank (2018). Overview. \{Online\} Available at: https://www.worldbank.org/en/country/yemen/

[32] Ayyagari, M., Kunt, A., and Maksimovic, V. (2011). Small vs. Young Firms across the World Contribution to Employment, Job Creation, and Growth.

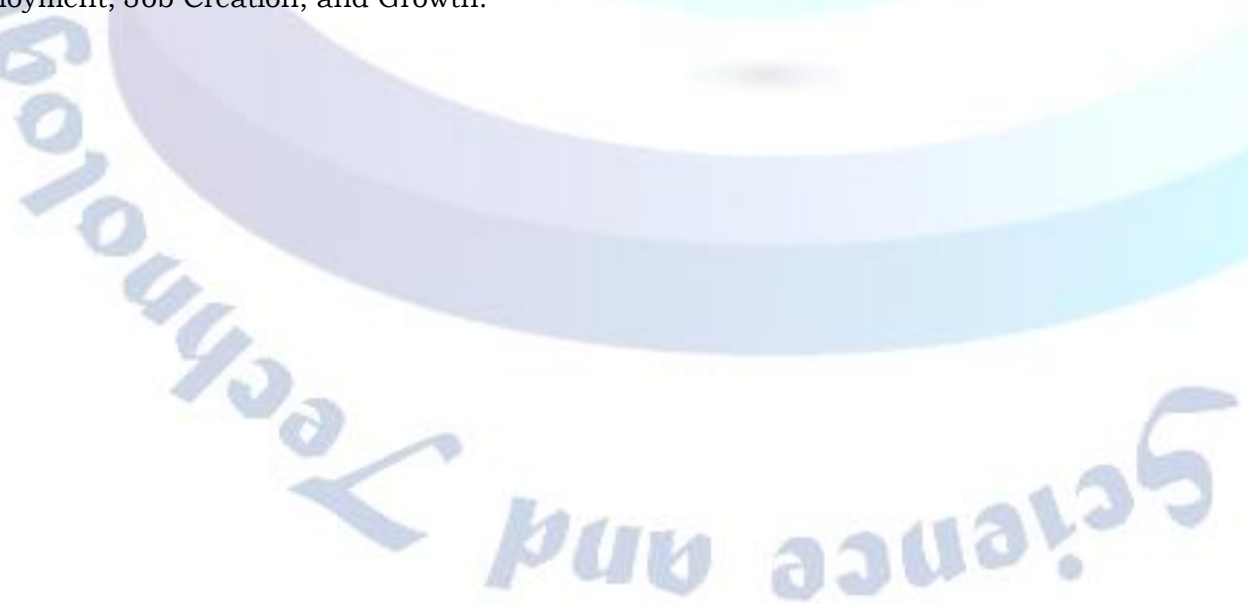

